\title{
Network-Based Accessibility Services For People With Disabilities
}

\author{
Jim Tobias \\ Inclusive Technologies \\ 37 Miriam Drive \\ Matawan, NJ, USA 07747 \\ tobias@inclusive.com
}

\begin{abstract}
Most assistive technologies (AT) are based on hardware and/or software installed and used by individuals. For example, a screen reader is installed on a computer so that a user can hear spoken output of the information on the display. However, a network-based screen reader, for example, would enable everyone in an organization (both with and without disabilities) to have access to the necessary text-to-speech and navigational capabilities on every computer, and to use them seamlessly with personalized settings. Network-based technologies can take advantage of certain economies and flexibility typically associated with thin-client environments. This article will describe such a system, now undergoing late-stage development.
\end{abstract}

AT, assistive technology, network, accessibility, disability.

\section{INTRODUCTION}

The predominant model for accessible technology assumes that consumers are using products right in front of them, such as computers and telephones. Whether the accessibility comes from a feature built into a mainstream product, or through the addition of an assistive device, the total package is used by one person at a time.

Networked technologies offer a different solution. The accessibility feature or features can exist within the network instead of within a hardware product. The user then accesses a customized service as needed, typically using a less-expensive mainstream terminal device. A number of developers and researchers [1,2,3] have commented on the potential of network-based accessibility services (NbAS), which can include speech technologies, translation, intelligent routing, and other features described below.

$\mathrm{NbAS}$ do not have to be technologically novel or advanced; it is their use of networks rather than their technical sophistication that distinguishes them. An example of an existing network-based accessibility service is the telecommunications relay service (TRS), or "deaf relay". This service allows TTY and voice phone users to communicate through a relay operator, who speaks the typed text and types the spoken replies. Consider the only equitable alternative to TRS: assigning an interpreter or transcriptionist to every deaf person, 24 hours a day, just in case the person wants to receive or place a telephone call. The network service provides equivalent functionality at a tiny fraction of the cost.

Another example is speech delivery of email or web content. Although these services were designed for nondisabled users, they can be effective assistive services for people who cannot access regular text or screens.

\section{A REPLACEMENT FOR ASSISTIVE TECHNOLOGIES?}

Network-based accessibility services are not intended to replace assistive technology devices. Rather they will offer an additional way of improving accessibility. The "replacement" concern expressed by some in the AT community is based on a false assumption: that there is one best technological solution to every barrier encountered by a person with a disability. This attitude is a holdover from a medical, prescriptive model of service delivery. In reality, people with disabilities need to have access to a wide range of solutions, from which they can select the ones that best fit their preferences and immediate environments of use. Just as non-disabled users choose from a wide range of enabling technologies, people with disabilities benefit from a rich ecology of solutions.

\section{NETWORK TECHNOLOGIES}

Each assistive functionality in the network can use one or more of six categories of technological capability: 
- Speech recognition. A common need for speech recognition is to convert a speaker's voice into text so it can be sent to a deaf person at the other end of a call; another is to convert a video actor's voice into text for captioning purposes.

- Speech synthesis. Conversely, speech synthesis can take text created by a person with impaired speech and deliver it to a hearing person at the other end of a call; speech synthesis can be used by a vision impaired person to listen to email or web content.

- Routing (automatic delivery or connection). For example, the network can send messages or calls to someone regardless of location, based on a schedule or network locator.

- Translation and medium conversion. The network element can translate between languages or convert from one medium to another, such as sign language to English text. Some of these gateway services already exist, such as TRS and the TTY-to-wireless text messaging service provided by Wyndtel.

- Interpretation and support. The service can help a user understand where they are, what to do next, etc. An example of this is "augmented reality", in which additional information is superimposed over a live video. A mainstream application would show English words over Japanese store signs; an accessibility application might interpret street signs to locate a person with a cognitive loss, and give them directions to their destination.

- Automatic setup. A service can automatically identify the user and establish the proper connections and service preferences. For example, an ID card can alert a network that the user in question prefers large print on the ATM he/she is using.

Note how many of these capabilities are already available in current networks for mainstream purposes.

\section{EXAMPLES OF NBAS TODAY}

As indicated in the Introduction, NbAS is not really an entirely new concept. There are several examples of NbAS already in operation; some of these are mainstream services rather than services initially designed to provide accommodations for people with disabilities:

- Telecommunications Relay Service (TRS), including video relay service (VRS)

- Video Remote Interpreting (VRI) uses a bank of sign language interpreters over video links to provide faceto-face interpreting

- Text-to-speech for email

- Text-to-speech for web content

- Speech-to-text for messaging or document creation (transcription)

\section{WHEN NBAS MAKES SENSE}

In certain use environments NbAS can have some interesting features and characteristics hard to match in personal assistive technologies.

When a network is already needed for a particular mainstream purpose, such as having a telephone conversation or retrieving email, adding a network resource may require little additional effort or expense. It may be the case that more information transactions and functions are performed in a "pervasive network" environment. Note that the NbAS need not be an inherent part of the mainstream network; it may be an affiliated network called upon by the mainstream network to provide its additional service.

Where provisioning a personal assistive technology for each user would be unfeasibly expensive, it may make sense to share a resource over a network. The TRS example fits here; this might also apply to high quality speech synthesis, currently too expensive or memory-intensive for most users' equipment.

NbAS may make sense in an arena where a wide range of hardware solutions exists, each of which would require expensive retro-engineering. For example, hundreds of models of wireless phones, all of which should be accessible to people with a wide range of functional limitations, would each require special re-engineering to meet those needs. There is no sign that the diversity of wireless handset platforms is diminishing or decelerating; thus the need for this re-engineering is costly and never-ending.

The NbAS prototype described below reflects all three of these scenarios.

\section{ADVANTAGES OF NBAS}

In addition to consumers with disabilities, there are several other stakeholders who may benefit from NbAS: clinicians, public and private agencies responsible for administering and paying for accessibility, and assistive technology companies. In the table below are descriptions of several advantages and how they affect these stakeholders. 


\begin{tabular}{|c|c|c|c|c|}
\hline & Users & Clinicians & $\begin{array}{l}\text { AT funding } \\
\text { programs }\end{array}$ & AT companies \\
\hline $\begin{array}{l}\text { Low } \\
\text { capital } \\
\text { cost } \\
\text { (main- } \\
\text { stream } \\
\text { terminal } \\
\text { device) }\end{array}$ & $\begin{array}{l}\text { Allows low income } \\
\text { users to } \\
\text { participate. }\end{array}$ & $\begin{array}{l}\text { Allows for } \\
\text { temporary } \\
\text { access to AT } \\
\text { for evaluation } \\
\text { and training } \\
\text { purposes }\end{array}$ & $\begin{array}{l}\text { May simplify public } \\
\text { funding and reduce } \\
\text { its cost per unit of } \\
\text { service. } \\
\text { Reduces the } \\
\text { financial risk of } \\
\text { abandoned } \\
\text { devices. }\end{array}$ & $\begin{array}{l}\text { Allows them to focus on } \\
\text { their specific added } \\
\text { value and marketing it, } \\
\text { rather than meeting the } \\
\text { challenges of small- } \\
\text { scale production and } \\
\text { distribution. }\end{array}$ \\
\hline $\begin{array}{l}\text { Remote } \\
\text { mainten- } \\
\text { ance }\end{array}$ & $\begin{array}{l}\text { Since the } \\
\text { technology is not } \\
\text { owned by the } \\
\text { user, there is less } \\
\text { concern about } \\
\text { maintenance. }\end{array}$ & $\begin{array}{l}\text { Technical } \\
\text { maintenance } \\
\text { is often a } \\
\text { weak point in } \\
\text { clinical } \\
\text { services }\end{array}$ & $\begin{array}{l}\text { Reduced } \\
\text { maintenance costs }\end{array}$ & $\begin{array}{l}\text { Reduced maintenance } \\
\text { costs, including } \\
\text { shipping and temporary } \\
\text { loaners. }\end{array}$ \\
\hline $\begin{array}{l}\text { Remote } \\
\text { upgrades }\end{array}$ & $\begin{array}{l}\text { Similarly, users do } \\
\text { not have to install } \\
\text { new versions, } \\
\text { because the } \\
\text { service owner } \\
\text { takes care of } \\
\text { upgrades. }\end{array}$ & $\begin{array}{l}\text { Technical } \\
\text { maintenance } \\
\text { is often a } \\
\text { weak point in } \\
\text { clinical } \\
\text { services }\end{array}$ & & $\begin{array}{l}\text { Reduced hardware } \\
\text { processing costs, } \\
\text { including shipping and } \\
\text { temporary loaners. }\end{array}$ \\
\hline $\begin{array}{l}\text { Porta- } \\
\text { bility }\end{array}$ & $\begin{array}{l}\text { Terminal devices } \\
\text { may be smaller } \\
\text { and lighter, and } \\
\text { be accessed from } \\
\text { anywhere. }\end{array}$ & $\begin{array}{l}\text { Reduced need } \\
\text { to transport } \\
\text { and set up } \\
\text { devices for } \\
\text { remote } \\
\text { evaluation. }\end{array}$ & & $\begin{array}{l}\text { Reduced marketing } \\
\text { costs due to lower } \\
\text { transport and setup } \\
\text { costs for demonstration }\end{array}$ \\
\hline Scaling & & & $\begin{array}{l}\text { Reduced cost per } \\
\text { unit of service }\end{array}$ & $\begin{array}{l}\text { No need for production } \\
\text { capability to change } \\
\text { according to usage. } \\
\text { Networks scale more } \\
\text { smoothly by responding } \\
\text { to small increases in } \\
\text { usage with small } \\
\text { increases in resources. }\end{array}$ \\
\hline
\end{tabular}

\section{NBAS PROTOTYPE}

A prototype is currently under development that demonstrates NbAS characteristics in a significant arena: wireless telephony. The Wireless Interconnection Network-based Assistive Service Experiment (WINbASE) uses speech synthesis, speech recognition, and network awareness to provide improved access to wireless voice telephony.

Consumers with disabilities have raised numerous concerns about the accessibility of wireless phones and phone services [4]. While these concerns are not limited to those with visual impairments, WINbASE addresses the issues most often raised by blind and low vision users:

- navigating a cell phone's user interface via an inaccessible LCD

- receiving caller information (CallerID)

- entering and using contact information

- receiving other status information (battery level, roaming, and antenna indicators)

WINbASE provides all this functionality.

1. Users access WINbASE from any phone through standard or abbreviated dialing, including wireless push-totalk.

2. WINbASE identifies the user via CallerID, active log in, or secure coding without user intervention.

3. WINbASE provides full phone functionality one of two ways:

3a. For "qualified" phones, WINbASE queries the phone's status and display, and then speaks the results to the user.

3b. WINbASE replicates basic phone functions on the WINbASE platform itself, including speed dial, CallerID, etc. Some functions are not available, such as battery level, roaming, and signal strength. 
4. Users can perform all phone functions with or without WINbASE as they choose on a per-call basis.

WINbASE is currently undergoing friendly user trials.

\section{CONCLUSION}

Network-based assistive services may offer an interesting and useful addition to the model for delivery of accessible technologies. The WINbASE prototype explores how a shared resource can provide improved wireless service at lower cost.

The hardware alternative to WINbASE is to provide speech synthesis technology to every model phone in use. This would not only be unfeasibly expensive, in some cases it would not even be technologically possible. Because of this, blind and low vision cell phone users are limited in their choice of handset, and may have to purchase expensive software upgrades to their phones out of pocket.

The WINbASE prototype replicates features found in expensive or scarce products, offering users greater functional coverage at potentially lower cost. In addition, it allows (but does not require) wireless service providers to participate in improving service to these customers.

\section{REFERENCES}

[1] Tobias, J. (1994) “Shared Resource Assistive Systems", Technology and Disability Journal, v.3, No. 3

[2] (August 2004) Interface Sockets, Remote Consoles, and Natural Language Agents: A V2 URC Standards Whitepaper (NCITS V2)

[3] Zimmerman, G., Vanderheiden, G., Gilman, A. (2002) "Internet-Based Personal Services on Demand" in Emerging and Accessible Telecommunications, Information, and Healthcare Technologies RESNA

[4] "How To Get An Accessible Telephone", American Foundation for the Blind; http://www.afb.org/Section.asp?SectionID=4\&DocumentID=1536 